\title{
Kıraç Koşullarda Orta Anadolu ve Geçit Bölgeleri İçin Geliş̧irilen Bazı Arpa (Hordeum vulgare L.) Hat ve Çeşitlerinin Tane Verim ve Bazı Kalite Unsurlarının İncelenmesi
}

\author{
Ali Cevat SÖNMEZ ${ }^{1}$ \\ Soner YÜKSEL ${ }^{1}$ \\ Mustafa ÇAKMAK ${ }^{1}$ \\ Yilmaz YILDIRIM ${ }^{1}$ \\ Savaş BELEN ${ }^{1}$ \\ Yaşar KARADUMAN $^{1} \quad$ Arzu AKIN $^{1}$ \\ ${ }^{1}$ Geçit Kuşağı Tarımsal Araştırma Enstitüsü Müdürlüğü, Eskişehir \\ $\triangle$ : alicevat.sonmez@tarim.gov.tr
}

Geliş (Received): 04.11.2017

Kabul (Accepted): 15.12.2017

\begin{abstract}
ÖZET: Bu araştırmada amaç, Orta Anadolu Bölgesinde kıraç koşullarda yüksek verimli, abiyotik ve biyotik streslere dayanıklı ve istenilen kalitede arpa çeşitlerinin ıslah edilmesi olup Geçit Kuşağı Tarımsal Araştırma Enstitüsü Müdürlüğü'nce (GKTAEM) yürütülen arpa 1slah projesi kapsamında 2012-2013 sezonu bölge verim denemesi seviyesinde yer alan 19 ' $u$ hat ve 5 'i standart çeşit (Ergine190, İnce04, Özdemir05, Keser ve Tarm92) olmak üzere 24 genotip kullanılmıştır. Denemeler 5 farklı çevrede tesadüf blokları deneme desenine göre 4 tekerrürlü olarak kurulmuştur. Araştırmada incelenen unsurlar tane verim (TV), bin tane ağırlığı (BTA) ve tane protein oranı (TPO)'dır. Bu çalışmada incelenen her üç parametre açısından genotipler ve çevreler arası farklılıklar ile genotip x çevre interaksiyonu önemli bulunmuştur. Araştırmada TV için deneme ortalaması 3.91 ton ha-1 olurken, standart çeşitlerin ortalaması 4.30 ton ha-1 olarak belirlenmiştir. Bu çalışmada 3, 4, 8, 16 ve 21 nolu hatların standartlar ortalamasının üzerinde TV elde edilirken bu hatların aynı zamanda diğerlerinden daha stabil oldukları tespit edilmiştir. En yüksek BTA ortalama $53 \mathrm{~g}$ ile 3 nolu hattan alınırken, en yüksek TPO \% 14.3 ortalama ile hat12'den elde edilmiştir. Çevrelere bakıldığında en yüksek TV ve BTA Eskişehir'den alınırken, en yüksek TPO Hamidiye çevresinden alınmıştır.
\end{abstract}

Anahtar kelimeler : Arpa, tane verim, bin tane ağırlı̆̆ı, tane protein oranı

\section{Evaluation of Grain Yield and Some Quality Traits of Advanced Barley (Hordeum vulgare L.) Genotypes and Cultivars Developed for Central Anatolia And Trasitional Zone Regions in Rainfed Condition}

\begin{abstract}
S: The purpose of this research is to improve the barley varieties with high yield, resistant to abiotic and biotic stresses and has quality characteristics required in rainfed conditions in Central Anatolia and Trasitional Zone Regions. In this research, 19 lines and 5 standard cultivars were used which carried out by the Trasitional Zone Agricultural Research Institute in the period of 2012-2013. Trials were established with randomized block design in 4 replications in 5 different environments. The factors investigated in the research are grain yield (GY), thousand grain weight (TGW) and grain protein ratio (GPR). The differences between genotypes and environments and genotype $x$ environment interaction were found significantly. For GY the average of the standard varieties was 4.30 tons ha-1 and the average of experiment was 3.91 tons ha-1. It was found that from lines 3, 4, 8, 16 and 21 were obtained above the average of the standards and these genotypes were more stable than others. The highest GPR was obtained from line 12 with $14.3 \%$ and the highest TGW was obtained from line 3 with $53 \mathrm{~g}$. The highest GY and TGW are obtained from Eskişehir.

Keywords : Barley, grain yields, thousand grain weight, grain protein ratio
\end{abstract}

\section{GíRiş}

Dünyanın en eski kültür bitkilerinden birisi olan arpa (Hordeum vulgare L.) Dünya'da ve Türkiye'de serin iklim tahılları içerisinde ekiliş ve üretim açısından buğdaydan sonra 2. sırayı alan tahıldır (Kün, 1988). Önceleri insan gıdası olarak arpa kullanımı yaygınken, zamanla bu alandaki önemini yitirmiştir. Geçtiğimiz yıl Türkiye'de 2.74 milyon hektar alanda 6.7 milyon ton arpa üretimi yapılmış olup ortalama TV 2.45 ton ha ${ }^{-1}$ olarak gerçekleşmiştir (Tuik, 2016). Geniş alanlarda üretilen ve çiftçimizin önemli bir gelir kaynağı olan arpanın üretim ve veriminin artırılması için ekolojik koşullara uyumlu çeşitlerin bulunması önemlidir (Turgut ve ark., 1997). Arpa Türkiye'nin tüm bölgelerinde yetiştirilmekle birlikte, özellikle Orta Anadolu ve Batı Geçit Bölgelerinde yoğun olarak yetiştirilmektedir. 2016 yılında bu bölgelerde 1,1 milyon hektar alanda 3,0 milyon ton arpa üretimi yapılmış olup Türkiye arpa üretiminin yaklaşık \% $45^{\prime}$ i karşılanmıştır (Tuik, 2016). Türkiye'nin kendine yeterli tarımsal ürünlerinden biri olan arpa, kaba ve karma yem açığının önemli bir bölümünün kapatılmasına yardımcı olmaktadır. Üretimin tamamına yakını iç piyasada tüketilen arpa'nın \% 95'i hayvan yemi olarak kullanılmakta geri kalanı ise malt sanayinde hammadde olarak kullanılmaktadır. Ayrıca arpa samanı da hayvan beslenmesinde çok önemli bir yere sahiptir. Ülkemizde ilk arpa 1slah çalışmalarına 1926 yılında Eskişehir Tohum Islah İstasyonunun kurulmasıyla başlanmış olup yerel çeşitlerden seleksiyon yöntemiyle ilk arpa çeşidimiz Güzak24 adıyla 1937 yılında Emcet Yektay tarafından Eskişehir de tescil ettirilmiştir. 1963 yılında Ankara Tarla Bitkileri Merkez Araştırma Enstitüsü tarafindan tescil ettirilen Tokak 157-37 isimli arpa 
çeşidi ise yüksek verim özelliği nedeniyle uzun ylllar çifţimiz tarafindan yaygın olarak ekilen çeşit olmuştur. Uzun yıllardan beri devam eden arpa sslah çalışmaları halen kamu ve özel sektörde birçok kuruluş tarafindan iki veya altı sıralı, yemlik, maltlık ve kavuzsuz arpa ıslah çalışmaları olarak devam etmektedir. $\mathrm{Bu}$ araştırmada amaç, Orta Anadolu ve Geçit Bölgelerinde kıraç koşullarda yüksek verimli, abiyotik ve biyotik streslere dayanıklı ve aranılan kalite özelliklerine sahip arpa çeşitlerinin sslah edilerek çiftçilerimize sunulması ve ülkemizin arpa üretiminin artırılmasına destek olunmasidır.

\section{MATERYAL ve YÖNTEM}

$\mathrm{Bu}$ araştırmada, GKTAEM tarafindan yürütülen arpa 1slah projesi kapsamında 2012-2013 sezonunda bölge verim denemesi seviyesinde yer alan 19 hat ve 5 çeşit kullanılmış olup hatların ebeveyn bilgileri Çizelge 1 'de verilmiştir. Denemeler Eskişehir, Hamidiye, Çumra, Kütahya ve Emirdağ bölgelerinde, tesadüf blokları deneme deseninde 4 tekerrürlü olarak kurulmuş olup Çumra çevresinden sadece tane verim sonuçları elde edilebilmiştir. Denemelerde ekimden önce diskli tırmık ile toprak işlemesi yapılmış olup denemelerin ekimi 20 $\mathrm{cm}$ sıra arası ile 6 sıralı parsel ekim mibzeri kullanılarak ekim ayında yapılmışıtır. Denemede $70 \mathrm{~kg} \mathrm{ha}^{-1} \mathrm{~N}$ ve 70 $\mathrm{kg} \mathrm{ha}^{-1} \mathrm{P}_{2} \mathrm{O}_{5}$ hesabıyla gübreleme yapılmıştır. Azotlu gübrenin yarısı ekimle birlikte diğer yarısı ise ilkbaharda sapa kalkma döneminde verilmiştir. Fosforlu gübrenin tamamı ekimle birlikte verilmiştir. Hastalık, zararlı ve yabancı ot yoğunluğu takip edilmiş ve geniş yapraklı yabancı otlarla mücadele için ilaçlama yapılmıştır. Hasatta parsel boyutu $1,2 \mathrm{~m}$ x $5 \mathrm{~m}$ olarak uygulanmış genotipler hasat olgunluğuna geldiğinde parsel biçerdöveri ile Temmuz ayı başında hasat edilmiştir. Denemede incelenen özellikler tane verim (TV), bin tane ağırlığ (BTA) ve tane protein oranı' (TPO) dır. TV parsel biçerdöveri ile hasat edilen parsellerden elde edilen ürün temizlendikten sonra gram cinsinden tartılmış ve ton ha ${ }^{-1}$, a çevrilerek hesaplanmıştır. BTA her parselden elde edilen üründen tesadüfen alınan tanelerden dört defa yüz tanesi sayllip hassas terazide tartılarak gram cinsinden hesap edilmiştir (Williams ve ark., 1988). TPO tam tane unu örneklerinde protein miktarı ICC Standart No: 105/1'e göre \% olarak hesaplanmıştır (Anonymus, 1960). Lokasyonlara göre yıllık ve uzun yıllar yağış değerleri şöyledir; Eskişehir (254-348 mm), Hamidiye (254-348 mm), Çumra (294$322 \mathrm{~mm}$ ), Kütahya (680-556 mm) ve Emirdağ (432-439 $\mathrm{mm}$ ) olarak bulunmuştur.

\section{BULGULAR ve TARTIŞMA}

Orta Anadolu ve Geçit Bölgesi için TV, BTA ve TPO yönünden yüksek performans gösteren genotiplerin tespit edilmesi amaciyla yapilan bu araştırmada elde edilen değerler varyans analizine tabi tutulmuş ve ' $\mathrm{f}$ ' testi yapılmak suretiyle farklılıklarının önemlilikleri bulunmuştur. Genotiplerin ortalama değerleri 'LSD' testine göre gruplandırılmıştır. Araştırmada incelenen parametreler aşağıda başlıklar halinde sunulmuştur.

\section{Tane verim (TV)}

$\mathrm{Bu}$ çalışmada yapılan varyans analizinde TV açısından çevreler ve genotipler arası farklılıklar ile genotip x çevre interaksiyonu \% 1 seviyesinde önemli bulunmuş olup ortalama TV değerleri ve gruplandırmaları Çizelge 1.'de verilmiştir. Çevreler değerlendirildiğinde en yüksek TV 4.90 ton ha ${ }^{-1}$ ile Eskişehir'den alınırken, en düşük TV 2.20 ton $\mathrm{ha}^{-1}$ ile Kütahya çevresinden alınmıştır. Genotiplerin deneme ortalamas1 3.91 ton $\mathrm{ha}^{-1}$ olurken, standart çeşitlerin ortalamasi 4.30 ton $\mathrm{ha}^{-1}$ olarak tespit edilmiştir. $\mathrm{Bu}$ çalışmada $3,4,7,8,16,19,21$ ve 22 nolu hatlardan deneme ortalamasının üzerinde TV elde edilirken, 21 nolu hattan standartlar ortalamasının üzerinde TV elde edilmiştir. En yüksek TV 4.64 ton ha ${ }^{-1}$ ile 10 nolu çeşitten alınırken, en düşük TV ise 2.87 ton $\mathrm{ha}^{-1}$ ile hat9'dan elde edilmiştir. Genotip x çevre interaksiyonu değerlendirildiğinde en yüksek TV 5.98 ton $\mathrm{h}^{-1}$ ile Eskişehir çevresinde hat 19'dan elde edilirken, en düşük TV 1.73 ton $\mathrm{ha}^{-1}$ ile Kütahya da hat9'dan elde edilmiştir. $\mathrm{Bu}$ çalışmada elde edilen sonuçlar benzer konuda yapılan birçok çalışma ile uyumlu bulunmuştur (Ayranc1, 2004; Aydoğan, 2011; İmamoğlu, 2016). Kalaycı ve ark. (1991) 'na göre arpada TV'i en fazla etkileyen çevre faktörleri gelişme döneminde alınan yağışın miktarı ve aylara göre dağılımı, sıcaklık, ekim anında toprak profilinde birikmiş nem miktarı, topraktaki alınabilir besin maddelerinin miktarı ve uygulanan kültürel tedbirler (ekim sıklı̆̆ı, ekim zamanı, tohum yatağı hazırlı̆̆ı, tohumluk kalitesi ve gübreleme) olarak suralanabilir. Genotipler TV yönünden değerlendirildiğinde hem TV hem de stabilite açısından en iyi genotipin İnce04 çeşidi olduğu, hatlar içersinde ise $3,4,8,16$ ve 21 numaralı hatların TV'leri diğerlerine göre daha yüksek ve daha stabil oldukları görülmüştür (Şekil 1.)

\section{Bin tane ăğtlı̆̆ (BTA)}

BTA tanenin irilik, dolgunluk, cllızlık durumu ve yanı sıra tane verimi hakkında da fikir vermesi bakımından önemli bir kalite unsurudur (Öztürk ve ark., 2007). Araştırmamızda yapılan varyans analizinde BTA yönünden çevreler ve genotipler arası farklılıklar ile genotip x çevre interaksiyonu istatistiksel olarak \% 1 seviyesinde önemli bulunmuş olup ortalama BTA değerleri ve bunların istatistiksel gruplandırmaları Çizelge 2.'te verilmiştir. Çevreler BTA yönünden değerlendirildiğinde en yüksek BTA $50.9 \mathrm{~g}$ ile Eskişehir'den alınırken, en düşük BTA $41.0 \mathrm{~g}$ ile Kütahya çevresinden alınmıştır. Çevrelerin iklim ve toprak yapısı farklılıkları nedeniyle farklılıkların önemli çıktı̆̆ düşünülmektedir. Genotipler değerlendirildiğinde en yüksek BTA $53.0 \mathrm{~g}$ ile hat3'ten alınırken en düşük BTA ise $34.3 \mathrm{~g}$ ile hat9'dan elde edilmiş olup deneme ortalaması 47.2 g olmuştur. Genotip $\mathrm{x}$ çevre interaksiyonu na bakıldığında en yüksek BTA $59 \mathrm{~g}$ ile hat3 genotipinden Hamidiye çevresinden alınırken en düşük BTA $29 \mathrm{~g}$ ile hat9 genotipinden Kütahya'dan alınmıştır. Arpada BTA verimi etkileyen önemli unsurlardan biri olup aynı zamanda protein oranı ile 
birlikte maltlık veya yemlik özellikte olduğunun hangisinde olduğunun belirlenmesinde önemli yer tutar. $\mathrm{Bu}$ araştırmada yüksek verim elde edilen genotiplerden elde edilen BTA değerlerinin ortalamanın üzerinde olması da BTA'nın tane verimi üzerinde önemli etkisinin olduğunu göstermektedir.

Çizelge 1. Denemede yer alan genotiplerin tane verim ortalamaları $\left(\right.$ ton ha $\left.{ }^{-1}\right)$, DK ve LSD değerleri

\begin{tabular}{|c|c|c|c|c|c|c|c|}
\hline Genotip & Çeşit- Melez & Emirdağ & Çumra & Eskişsehir & Hamidiye & Kütahya & Ortalama** \\
\hline 1 & GK OMEGA/ERG-90 & $3.88 \mathrm{~d}-\mathrm{i}$ & $3.85 \mathrm{~g}-\mathrm{k}$ & $4.48 \mathrm{~g}-\mathrm{j}$ & $3.73 \mathrm{fgh}$ & 1.99 & $3.57 \mathrm{jkl}$ \\
\hline 2 & TARM-92/VICTORIA & $3.87 \mathrm{~d}-\mathrm{i}$ & $4.11 \mathrm{e}-\mathrm{j}$ & $4.76 \mathrm{c}-\mathrm{h}$ & $3.04 \mathrm{ijk}$ & 2.02 & $3.55 \mathrm{kl}$ \\
\hline 3 & KALAYCI/97-98DH9 & $4.31 \mathrm{c}-\mathrm{f}$ & $4.35 \mathrm{c}-\mathrm{g}$ & $5.55 \mathrm{a}-\mathrm{d}$ & $4.83 \mathrm{~b}$ & 2.3 & $4.26 \mathrm{bcd}$ \\
\hline 4 & KALAYCI/97-98DH9 & $4.32 \mathrm{c}-\mathrm{f}$ & 4.63 cde & $5.27 \mathrm{a}-\mathrm{g}$ & $4.38 \mathrm{~b}-\mathrm{f}$ & 2.01 & $4.11 \mathrm{~d}-\mathrm{g}$ \\
\hline 5 & ERGİNEL90 & $3.42 \mathrm{f}-\mathrm{i}$ & $4.58 \mathrm{c}-\mathrm{f}$ & $4.77 \mathrm{c}-\mathrm{h}$ & 3.68 ghi & 2.04 & $3.69 \mathrm{~h}-\mathrm{l}$ \\
\hline 6 & EFES-98/ERG-90 & $4.01 \mathrm{~d}-\mathrm{g}$ & $4.61 \mathrm{cde}$ & $4.68 \mathrm{e}-\mathrm{i}$ & $4.09 \mathrm{c}-\mathrm{g}$ & 1.92 & $3.85 \mathrm{f}-\mathrm{k}$ \\
\hline 7 & TARM-92/VICTORIA & $4.37 \mathrm{~b}-\mathrm{f}$ & $4.03 \mathrm{f}-\mathrm{j}$ & $5.58 \mathrm{abc}$ & $3.79 \mathrm{e}-\mathrm{h}$ & 2.61 & $4.06 \mathrm{~d}-\mathrm{h}$ \\
\hline 8 & Clerine/4/ERG//364TH/TOK/3/ERG & $4.46 \mathrm{~b}-\mathrm{e}$ & $4.20 \mathrm{~d}-\mathrm{i}$ & $5.34 \mathrm{a}-\mathrm{f}$ & $4.67 \mathrm{bc}$ & 2.29 & $4.18 \mathrm{c}-\mathrm{f}$ \\
\hline 9 & Bilinmeyen/ST5819 & $2.98 \mathrm{i}$ & $3.46 \mathrm{k}$ & $3.89 \mathrm{ij}$ & $2.36 \mathrm{k}$ & 1.73 & $2.87 \mathrm{n}$ \\
\hline 10 & İNCE 04 & $5.15 \mathrm{abc}$ & $4.34 \mathrm{c}-\mathrm{h}$ & 5.48 a-e & $5.88 \mathrm{a}$ & 2.44 & $4.64 \mathrm{a}$ \\
\hline 11 & 4673//3896/GZK/3/IMPACT & $4.06 \mathrm{~d}-\mathrm{g}$ & $3.78 \mathrm{~h}-\mathrm{k}$ & $4.75 \mathrm{~d}-\mathrm{h}$ & $4.19 \mathrm{~b}-\mathrm{g}$ & 2.01 & $3.75 \mathrm{~g}-1$ \\
\hline 12 & ERG//ROHO/MASURKA & 3.18 ghi & $3.58 \mathrm{jk}$ & 4.03 hij & $2.76 \mathrm{jk}$ & 1.95 & $3.09 \mathrm{mn}$ \\
\hline 13 & IMPACT/Tokak & $3.99 \mathrm{~d}-\mathrm{h}$ & $3.87 \mathrm{~g}-\mathrm{k}$ & $4.63 \mathrm{f}-\mathrm{i}$ & $3.82 \mathrm{e}-\mathrm{h}$ & 2.07 & $3.67 \mathrm{i}-1$ \\
\hline 14 & ANGORA/ST4846 & $3.04 \mathrm{hi}$ & $4.32 \mathrm{c}-\mathrm{h}$ & $4.93 \mathrm{~b}-\mathrm{g}$ & $3.34 \mathrm{hij}$ & 2.19 & $3.55 \mathrm{kl}$ \\
\hline 15 & ÖZDEMIR 05 & $5.31 \mathrm{ab}$ & $5.28 \mathrm{ab}$ & $4.81 \mathrm{~b}-\mathrm{h}$ & $4.83 \mathrm{~b}$ & 2.68 & $4.57 \mathrm{ab}$ \\
\hline 16 & ERG/ST4517 & $4.06 \mathrm{~d}-\mathrm{g}$ & $4.74 \mathrm{bcd}$ & $4.70 \mathrm{e}-\mathrm{i}$ & $4.34 \mathrm{~b}-\mathrm{g}$ & 2.03 & $3.96 \mathrm{~d}-\mathrm{i}$ \\
\hline 17 & IMPACT/Tokak & $3.58 \mathrm{e}-\mathrm{i}$ & $4.32 \mathrm{c}-\mathrm{h}$ & $4.74 \mathrm{~d}-\mathrm{h}$ & $4.52 \mathrm{bcd}$ & 2.27 & $3.87 \mathrm{e}-\mathrm{k}$ \\
\hline 18 & ERG/97-98DH9 & $3.44 \mathrm{f}-\mathrm{i}$ & $3.74 \mathrm{ijk}$ & $4.86 \mathrm{~b}-\mathrm{g}$ & $3.32 \mathrm{hij}$ & 1.87 & $3.43 \mathrm{~m}$ \\
\hline 19 & IMPACT/Tokak & $4.47 \mathrm{~b}-\mathrm{e}$ & $4.07 \mathrm{e}-\mathrm{j}$ & $5.98 \mathrm{a}$ & $4.45 \mathrm{~b}-\mathrm{e}$ & 2.34 & $4.25 \mathrm{~b}-\mathrm{e}$ \\
\hline 20 & KESER & $5.21 \mathrm{abc}$ & $4.76 \mathrm{bcd}$ & $3.73 \mathrm{j}$ & $4.27 \mathrm{~b}-\mathrm{g}$ & 2.56 & $4.09 \mathrm{~d}-\mathrm{g}$ \\
\hline 21 & ADAY-1//CWB117-77-9-7/Grivita & $4.63 \mathrm{bcd}$ & $4.77 \mathrm{bc}$ & $5.85 \mathrm{a}$ & $4.66 \mathrm{bc}$ & 2.94 & $4.56 \mathrm{ab}$ \\
\hline 22 & 344 (315/OBZOR)//GKOMEGA & $3.77 \mathrm{~d}-\mathrm{i}$ & $4.32 \mathrm{c}-\mathrm{h}$ & $5.62 \mathrm{ab}$ & $3.85 \mathrm{~d}-\mathrm{h}$ & 2.24 & $3.95 \mathrm{~d}-\mathrm{j}$ \\
\hline 23 & K-305/2//WKN5185/82 & $3.95 \mathrm{~d}-\mathrm{h}$ & $4.37 \mathrm{c}-\mathrm{g}$ & $4.66 \mathrm{f}-\mathrm{i}$ & $4.454 b-e$ & 2.12 & $3.90 \mathrm{~d}-\mathrm{k}$ \\
\hline 24 & TARM92 & $5.63 \mathrm{a}$ & $5.68 \mathrm{a}$ & $4.56 \mathrm{f}-\mathrm{i}$ & $4.47 \mathrm{~b}-\mathrm{e}$ & 2.29 & $4.51 \mathrm{abc}$ \\
\hline Ortalama** & & $4.06 \mathrm{c}$ & $4.32 \mathrm{~b}$ & $4.90 \mathrm{a}$ & $4.07 \mathrm{c}$ & $2.20 \mathrm{~d}$ & 3.91 \\
\hline D.K. $(\%)$ & & 14.18 & 9.2 & 11.89 & 11.98 & 30.9 & 15.09 \\
\hline $\operatorname{LSD}(0,05)$ & & 96.21 & 56.15 & 82.24 & 68.8 & 96.15 & 37.97 \\
\hline
\end{tabular}

**: istatistiki olarak \% 1' de önemli; * istatistiki olarak \% 5’te önemli Aynı harflerle gosterilen ortalamalar arasında fark yoktur.

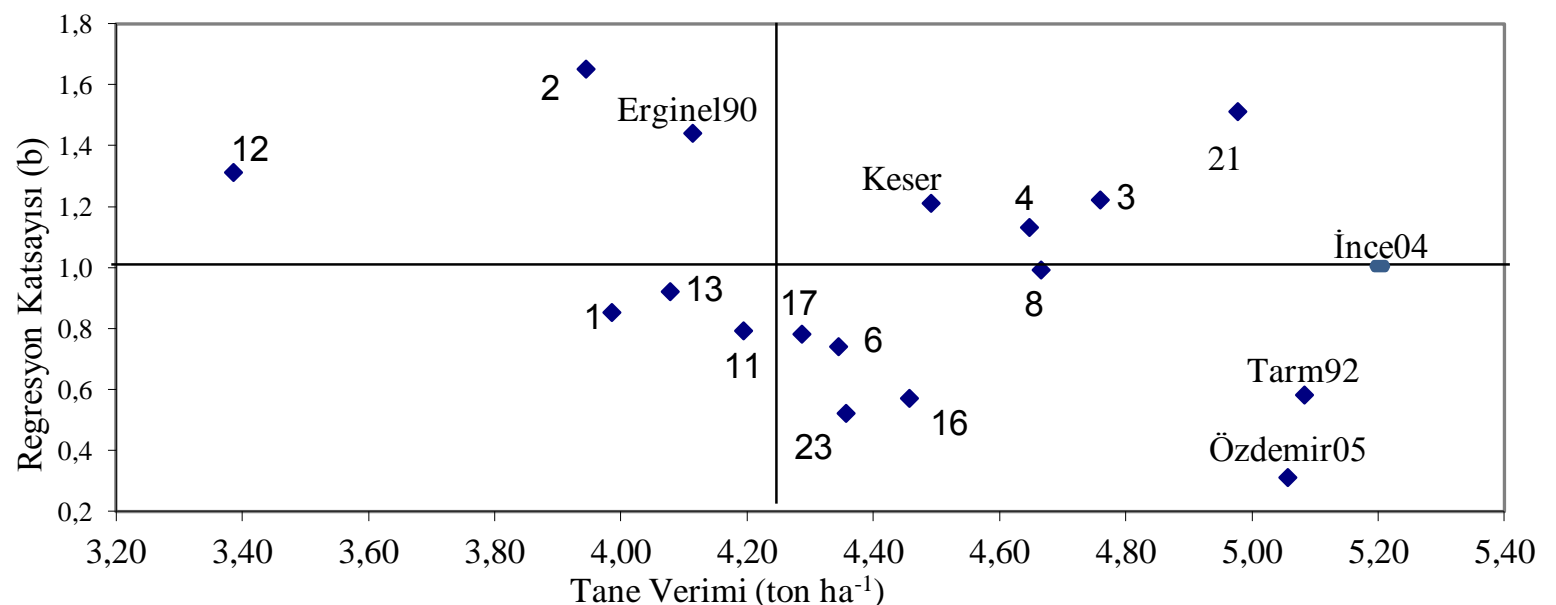

Şekil 1. Genotiplerin tane verim stabilite grafiği (Eskişehir, Hamidiye, Emirdağ ve Çumra) 


\section{Tane protein oranı (TPO)}

Arpada TPO maltllk ve yemlik karakterlerle ilgili olup, maltllk çeşitlerde düşük, yemlik çeşitlerde ise yüksek TPO istenmektedir (Kün vd., 1992). Arpa tanesi, yaklaşık olarak \% 7.5-15 TPO içerir (Akkaya ve Atken 1986). Bu çalışmada TPO değerleri \%10.0 ile 15.5 arasında değişmiştir. $\mathrm{Bu}$ elde edilen TPO değerleri yapılan diğer çalışmalarla uyumludur (Öztürk ve ark., 2007; Aydoğan ve ark., 2011; Doğan ve ark., 2011). TPO genotip, yetiştirme koşulları, ekim mevsimi ve iklime göre değiş̧iklik göstermektedir. Bu çalışmada yapılan varyans analizinde TPO açısından çevreler ve genotipler arası farkll1ıklar ile genotip $\mathrm{x}$ çevre interaksiyonu istatistiksel olarak $\% \quad 1$ seviyesinde önemli bulunmuş olup ortalama TPO değerleri ve bunların istatistiksel gruplandırmaları Çizelge 2.'te verilmiştir. Çevreler TPO yönünden değerlendirildiğinde en yüksek TPO $\% \quad 13.9$ ile Hamidiye'den alınırken, en düşük TPO \% 11.7 ile yine en düşük TV ve en düşük BTA değerleri elde edilen Kütahya çevresinden alınmıştır. TPO'nın arpada genetik özelliklerden ziyade çevreden etkilenen bir özellik olduğu bildirilmiştir (Atlı ve ark. 1989). Çevrelerde elde edilen TPO değerlerindeki farklılıkların iklim koşullarının farklılığı sebebiyle oluştuğu düşünülmektedir. Genotipler değerlendirildiğinde en yüksek TPO \% 14.3 ile hat12'den alınırken en düşük TPO ise \% 11.9 ile Keser çeşidinden elde edilmiş olup deneme ortalaması \% 12.8 olmuştur. Genotip x çevre interaksiyonuna bakıldığında en yüksek TPO \% 15.5 ile hat2 genotipinden Hamidiye çevresinden alınırken en düşük TPO \%10.0 ile hat3 genotipinden Kütahya'dan alınmıştır.

Çizelge 2. Çevrelere göre genotiplerin bazı kalite özellikleri

\begin{tabular}{|c|c|c|c|c|c|c|c|c|c|c|c|}
\hline \multirow{3}{*}{$\frac{\text { Genotip }}{1}$} & \multicolumn{5}{|c|}{ Bin Tane Ağırlı̆̆ 1 (g) } & \multicolumn{6}{|c|}{ Tane Protein Oranı (\%) } \\
\hline & \multirow{2}{*}{$\frac{\text { Emirdağ }}{51}$} & \multirow{2}{*}{$\begin{array}{c}\text { Eskişehir } \\
52\end{array}$} & \multirow{2}{*}{$\begin{array}{c}\text { Hamidiye } \\
53\end{array}$} & \multirow{2}{*}{$\frac{\text { Kütahya }}{46}$} & Ort. ** & \multirow{2}{*}{$\frac{\text { Emirdağ }}{13.4}$} & \multirow{2}{*}{$\begin{array}{c}\text { Eskişehir } \\
10.7\end{array}$} & \multirow{2}{*}{$\frac{\text { Hamidiye }}{14.6}$} & \multirow{2}{*}{$\begin{array}{c}\text { Kütahya } \\
11.1\end{array}$} & \multicolumn{2}{|c|}{ Ort. $* *$} \\
\hline & & & & & 50.5 a-d & & & & & 12.4 & $f-i$ \\
\hline 2 & 50 & 47 & 48 & 42 & $46.8 \mathrm{def}$ & 13.0 & 12.1 & 15.5 & 10.9 & 12.9 & $\mathrm{c}-\mathrm{h}$ \\
\hline 3 & 53 & 57 & 59 & 43 & $53.0 \mathrm{~A}$ & 13.0 & 11.6 & 14.0 & 10.0 & 12.1 & $\mathrm{Hi}$ \\
\hline 4 & 54 & 55 & 55 & 40 & 51.0 a-d & 14.9 & 12.8 & 14.4 & 12.0 & 13.5 & $a-d$ \\
\hline 5 & 38 & 39 & 39 & 32 & $37.0 \mathrm{H}$ & 13.2 & 12.6 & 12.2 & 11.0 & 12.3 & ghi \\
\hline 6 & 54 & 50 & 57 & 45 & $51.5 \mathrm{ab}$ & 14.9 & 12.3 & 15.0 & 10.3 & 13.1 & $c-f$ \\
\hline 7 & 42 & 45 & 40 & 39 & $41.5 \mathrm{G}$ & 14.4 & 11.7 & 14.3 & 10.6 & 12.8 & d-h \\
\hline 8 & 50 & 56 & 51 & 38 & 48.8 a-f & 13.0 & 11.7 & 13.9 & 11.0 & 12.4 & $f-i$ \\
\hline 9 & 33 & 37 & 57 & 29 & $34.3 \mathrm{H}$ & 12.9 & 12.3 & 14.2 & 12.1 & 12.9 & $c-h$ \\
\hline 10 & 50 & 46 & 47 & 42 & 48.8 a-f & 10.4 & 12.8 & 13.5 & 11.9 & 12.1 & $\mathrm{Hi}$ \\
\hline 11 & 45 & 48 & 52 & 38 & $44.5 \mathrm{fg}$ & 11.7 & 14.4 & 15.0 & 14.8 & 14.0 & $\mathrm{Ab}$ \\
\hline 12 & 52 & 55 & 51 & 46 & $51.3 \mathrm{abc}$ & 12.9 & 14.7 & 15.0 & 14.7 & 14.3 & $\mathrm{a}$ \\
\hline 13 & 52 & 52 & 40 & 44 & 49.8 a-e & 11.7 & 13.3 & 14.1 & 14.0 & 13.3 & $b-e$ \\
\hline 14 & 43 & 59 & 44 & 41 & $45.8 \mathrm{efg}$ & 12.7 & 12.5 & 14.3 & 14.7 & 13.5 & $a-d$ \\
\hline 15 & 44 & 50 & 52 & 40 & $44.5 \mathrm{fg}$ & 12.4 & 13.6 & 13.4 & 12.7 & 13.0 & $c-g$ \\
\hline 16 & 50 & 53 & 51 & 42 & 49.3 a-e & 14.2 & 12.9 & 14.6 & 12.7 & 13.6 & $a b c$ \\
\hline 17 & 46 & 53 & 50 & 39 & 47.3 b-f & 13.4 & 12.0 & 13.0 & 11.5 & 12.5 & $f-i$ \\
\hline 18 & 49 & 52 & 53 & 45 & 49.0 a-e & 13.6 & 13.3 & 14.2 & 12.1 & 13.3 & $b-e$ \\
\hline 19 & 50 & 55 & 48 & 43 & 50.3 a-d & 12.8 & 13.6 & 13.3 & 10.1 & 12.5 & $f-i$ \\
\hline 20 & 51 & 48 & 45 & 41 & $47.0 \quad c-f$ & 11.5 & 13.2 & 12.6 & 10.2 & 11.9 & $\mathrm{i}$ \\
\hline 21 & 49 & 54 & 45 & 45 & $48.3 \quad b-f$ & 12.5 & 13.1 & 13.5 & 10.7 & 12.5 & $f-i$ \\
\hline 22 & 48 & 55 & 51 & 39 & $46.8 \mathrm{def}$ & 13.2 & 13.0 & 12.5 & 11.1 & 12.4 & $f-i$ \\
\hline 23 & 51 & 53 & 43 & 42 & 49.3 a-e & 13.8 & 13.5 & 12.8 & 10.1 & 12.6 & $e-i$ \\
\hline 24 & 50 & 51 & 38 & 43 & $46.8 \mathrm{def}$ & 12.1 & 12.9 & 13.9 & 10.4 & 12.3 & $f-i$ \\
\hline Ort.** & $48.1 \mathrm{c}$ & $50.9 \mathrm{a}$ & $48.7 \mathrm{~b}$ & $41.0 \mathrm{~d}$ & 47.2 & $13.0 \mathrm{~b}$ & $12.8 \mathrm{c}$ & $13.9 \mathrm{a}$ & $11.7 \mathrm{~d}$ & 12.8 & \\
\hline D.K (\%) & & & & & 7.79 & & & & & 8.58 & \\
\hline $\operatorname{LSD}(0,05)$ & & & & & 0.81 & & & & & 1.64 & \\
\hline
\end{tabular}




\section{SONUC}

$\mathrm{Bu}$ araştırmada, denemeye alınan 3, 4, 8, 16 ve 21 nolu hatlar TV, verim stabilitesi ve BTA yönünden öne çıkmış olup bu hatlar ümitvar bulunarak bir üst kademe denemeye aktarılmıştır. Seçilen 4 ve 16 numaralı hatların ise TPO deneme ortalamasının üzerinde olup yemlik ümitvar hatlar olarak değerlendirilmesi öne çıkarken 3,8 ve 21 numaralı hatların TPO larının düşük olması ve aynı zamanda BTA'nın deneme ortalamasının üzerinde olması sebebi ile maltlı olarak değerlendirilebilecekleri düşünülmektedir.

\section{KAYNAKLAR}

Anonymous 1960. International Association for Cereal Chemistry ICC Standart No:105.

Akkaya A, \& Akten Ş (1986). Kıraç koşullarda farklı gübre uygulamalarının bazı kışlık arpa çeşitlerinde kışa dayanıklılık ve dane verimi ile bazı verim öğelerine etkisi. Doğa, Tr. Tarım Orm. Dergisi, 10(2), 127-140.

Aydoğan S, Şahin M, Akçacık A. G, \& Ayrancı R (2011). Konya Koşullarına Uygun Yüksek Verimli ve Kaliteli Arpa Genotiplerinin Belirlenmesi. Selçuk Tar.Bil.Der. 25(1), 10-16.

Atlı A, Koçak N, Köksal ve Tuncer T (1989). Yemlik ve Maltlık arpada kalite kriterleri ve arpa 1slahı programlarında kalite değerlendilirmesi. Arpa-Malt Seminerleri, 30 Mayıs-1 Haziran, Konya.

Bell M.A, and Fischer R.A 1994. Guide to plant and crop sampling: measurments and observations for agronomic and physiological research in small grain cereals, Wheat Special Report No. 32, CIMMYT.

Doğan Y, Kendal E, Karahan T, Çiftçi V 2014. Diyarbakır Koşullarında Bazı Arpa Genotiplerinde Verim ve Bazı Kalite Özelliklerinin Belirlenmesi. JAFAG, 31(2): 31-40.
Elgün A, Ertugay Z, Certel M, Kotancilar H.G 2012, Tahıl ve Ürünlerinde Analitik Kalite Kontrolü ve Laboratuvar Uygulama Kılavuzu. Düzeltilmiş Dördüncü Bask1. Atatürk Üniversitesi Yayın No:867 Erzurum

İmamoğlu A, Pelit S, Sarı N, Büyükkileci C, \& Yıldız Ö (2016). Ege Bölgesi Sahil Kuşağına Uyumlu Arpa (Hordeum vulgare L.) Çeşit ve Genotiplerinin Verim ve Bazı Kalite Özelliklerinin Belirlenmesi.

Kalaycı M, S. Siirt, M., Aydın ve K. Özbek.1991. Yıllık Çalışma Raporu. Geçit Kuşağı Tarımsal Araştırma Enstitüsü. Eskişehir.

Kün E 1988. Serin iklim tahılları ders kitabı. A.U.Z.F.Yayınları, Yayın No: 1032/299, s:187-195, Ankara

Kün E, Özgen., M ve Ulukan, H. 1992. Arpa Çeşit ve Hatlarının Kalite Özellikleri Üzerinde Araştırmalar. II. Arpa-Malt Semineri, 25-27 Mayıs 1992, Konya, 70-95.

Öztürk İ, Avcı R, and Kahraman T 2007. Trakya bölgesinde yetiştirilen bazı arpa (Hordeum vulgare L) çeşitlerinin verim ve verim unsurları ile bazı kalite özelliklerinin belirlenmesi. U. Ü. Ziraat Fakültesi Dergisi, 21 (1): 59-68

TUIKK 2016. www.tuik.gov.tr Erişim tarihi : 23/07/2017

Turgut I, Konak C, Zeybek A, Acartürk E, ve Yılmaz R 1997. Büyük Menderes Havzası Sulu Koşullarına Uyumlu Buğday Çeşitlerinin Belirlenmesi Üzerine Araştırmalar. Türkiye II. Tarla Bitkileri Kongresi, 22-25 Eylül 1997, 520-527 Samsun.

Williams P, El-Haramein F. J, Nakkoul H, \& Rihawi S (1988). Crop quality evaluation methods and guidelines. Crop quality evaluation methods and guidelines., (14, Ed. 2.). 